\title{
New-onset Polymyalgia Rheumatica Following the Administration of the Pfizer-BioNTech COVID-19 Vaccine
}

\author{
Atsumu Osada ${ }^{1}$, Chinatsu Sakuragi ${ }^{1}$, Chisashi Toya ${ }^{2}$ and Akiko Mitsuo ${ }^{1}$
}

\begin{abstract}
:
We herein report the case of an 80-year-old Japanese woman who presented to our hospital with bilateral pain in the shoulders and hips lasting for a month since 2 days after the second dose of the BNT162b2 COVID-19 vaccine. Her physical findings, laboratory data, and ultrasonographic findings of bilateral biceps tenosynovitis and lateral subacromial bursitis were consistent with a diagnosis of polymyalgia rheumatica (PMR). She was successfully treated with oral prednisolone $15 \mathrm{mg} /$ day. Although a causal relationship could not be definitively confirmed, PMR should be considered as a differential diagnosis in cases of persistent myalgia after administration of the BNT162b2 vaccine.
\end{abstract}

Key words: Polymyalgia rheumatica, COVID-19 vaccine, Adverse effect

(Intern Med Advance Publication)

(DOI: 10.2169/internalmedicine.8651-21)

\section{Introduction}

Polymyalgia rheumatica (PMR) is a common inflammatory disease in people over 50 years old that involves bilateral pain and stiffness in the shoulders and hips (1). In patients with PMR, infiltration of macrophages and CD45RO ${ }^{+}$ $\mathrm{T}$ cells and the expression of adhesion molecules, such as VCAM-1 and ICAM-1, have been observed in the synovia of the shoulders $(2,3)$. It has also been reported that interleukin 6 levels are increased in the shoulder joints $(4,5)$. One study found a decrease in $\mathrm{CD} 4^{+} \mathrm{CD} 25^{\text {high }} \mathrm{Foxp}^{+}$regulatory $\mathrm{T}$ cells and an increase in pro-inflammatory $\mathrm{T}$ cell subsets, such as Th1 and Th17, in the peripheral blood of PMR patients (6). Recent studies have revealed that cytokine production by $\mathrm{CD}^{+} \mathrm{T}$ and innate-like $\mathrm{T}$ cells in peripheral blood is associated with disease activity in PMR (7). However, the detailed etiology of PMR remains poorly understood.

The Pfizer-BioNTech COVID-19 vaccine (BNT162b2) was developed and deployed in 2020 with the aim of ending the global COVID-19 pandemic. BNT162b2 is composed of single-stranded messenger RNA (mRNA) with modified nucleosides encoding the SARS-CoV-2 spike protein and lipid shells to encapsulate the mRNA (8). The high efficacy and safety of BNT162b2 have been demonstrated in multiple clinical trials $(8,9)$. However, there have been very few reports of new-onset immune diseases, such as vasculitis, arthritis, myasthenia gravis, and idiopathic myocarditis, after the administration of the vaccine (10). In addition, several reports have described the development of PMR after the administration of BNT162b2 (10-12).

We herein report a case of new-onset PMR with typical clinical findings that occurred after BNT162b2 vaccination and was successfully treated with prednisolone.

\section{Case Report}

An 80-year-old Japanese woman presented to our hospital with bilateral pain in the shoulders and hips that had lasted for a month. She had received the first dose of BNT162b2 48 days earlier, and she developed a fever the same day that continued to the next day. In addition, on the day after the first dose, she had pain in the back of her neck, both shoulders, hips, knees, and legs lasting for 10 days. She received the second dose of BNT162b2 after the advised three-week interval with prophylactic administration of paracetamol for two days. After discontinuing paracetamol, she developed

${ }^{1}$ Division of Rheumatology, National Hospital Organization Disaster Medical Center, Japan and ${ }^{2}$ Division of Cardiology, National Hospital Organization Disaster Medical Center, Japan

Received: September 10, 2021; Accepted: November 1, 2021; Advance Publication by J-STAGE: December 11, 2021

Correspondence to Dr. Atsumu Osada, atsumu-osada-8074@hotmail.co.jp 

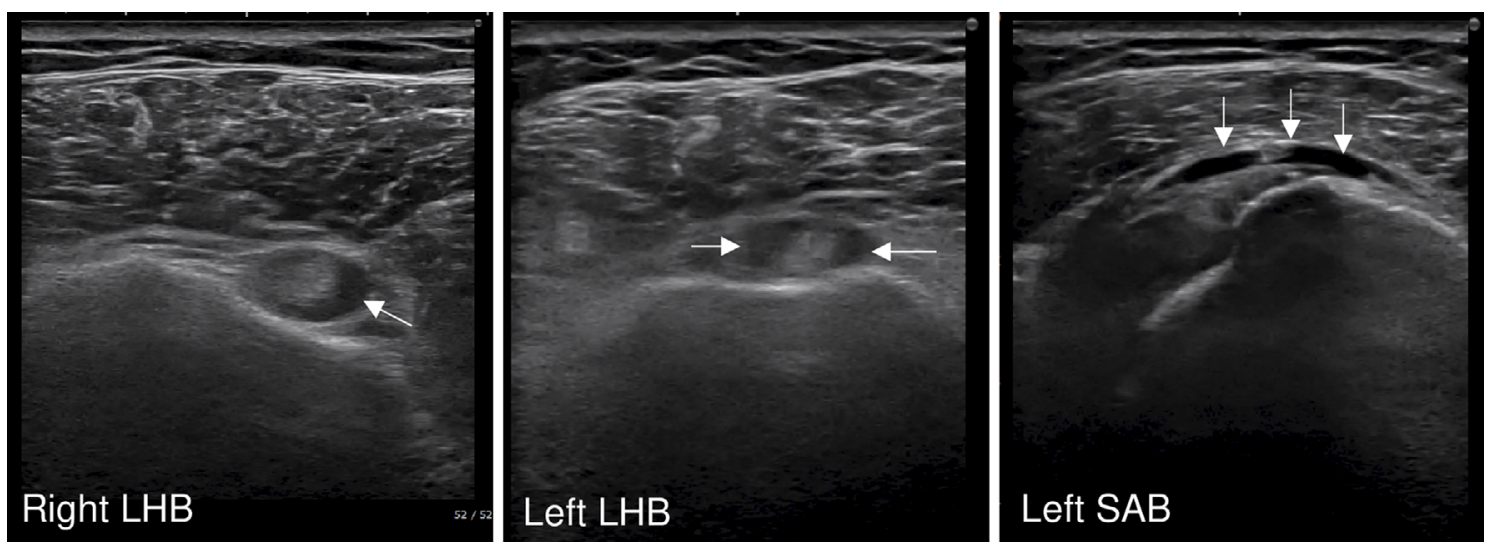

Figure 1. Ultrasonographic findings of the shoulders. Ultrasonography revealed effusion (arrows) around the right (first column) and left (second column) side of the long head of the biceps (LHB) tendon and the left subacromial bursa (SAB) (third column).

the same pain accompanied by a low-grade fever around 38 ${ }^{\circ} \mathrm{C}$, which persisted for 4 weeks. She had great difficulty turning over in bed and getting out of bed. She experienced morning stiffness lasting for $60 \mathrm{~min}$. She had fatigue and lost $1 \mathrm{~kg}$ in a month. She did not experience headache, jaw claudication, visual disturbance, skin manifestations, or neurological disorder. She had no history of rheumatic disease, except for osteoarthritis of the knees.

A physical examination revealed restricted abduction of both shoulders below the shoulder girdle and tenderness in the upper and lower proximal limbs. Temporal artery tenderness and decreased temporal artery pulse were not observed. There were no swollen joints in the fingers or wrists and no signs of enthesitis.

Laboratory data showed an elevated erythrocyte segmentation rate $(96 \mathrm{~mm} / \mathrm{h})$, C-reactive protein (CRP) level $(5.83$ $\mathrm{mg} / \mathrm{dL})$, and platelet count $\left(36.2 \times 10^{4} / \mu \mathrm{L}\right)$, while her serum albumin $(3.0 \mathrm{~g} / \mathrm{dL})$ and hemoglobin $(10.0 \mathrm{~g} / \mathrm{L})$ levels were decreased with a normal mean corpuscular volume (88.2 $\mathrm{fL})$. Muscle enzymes, thyroid function tests, and serum calcium levels were normal. Immunology findings were negative, including for rheumatoid factor, anti-cyclic citrullinated peptide antibody, PR3-ANCA, and MPO-ANCA. Notably, her serum matrix metalloproteinase-3 level was elevated (219.6 ng/mL; normal range: 17.3-59.7 ng/mL). Ultrasonography revealed effusion in the left subacromial bursa and around the long head of the biceps tendons bilaterally (Fig. 1). Whole-body computed tomography showed no evidence of malignancy, infection, or vasculitis. Esophagogastroduodenoscopy showed no signs of malignancy. Fecal occult blood was negative on two separate tests. No organisms were isolated in a blood culture, and a nose swab nucleic acid amplification test for SARS-CoV-2 was negative.

Based on the 2012 ACR/EULAR criteria with a total score of 5 (13), her clinical findings were compatible with a diagnosis of PMR. Therefore, oral prednisolone $15 \mathrm{mg} /$ day was initiated, leading to immediate improvement of her symptoms and inflammatory serum markers. The clinical course of this case is shown in Fig. 2.

\section{Discussion}

Given that the rheumatic symptoms in our patient appeared after the administration of the first dose and again soon after the administration of the second dose and then became chronic, we considered that there was a potential relationship between the vaccination and the development of PMR.

BNT162b2 is a novel product platform composed of single-stranded mRNA encoding the SARS-CoV-2 spike protein (8). An analysis of patients' serum using an antibody panel has suggested preceding infection with several viruses as a possible trigger for the onset of PMR $(14,15)$. In addition, the increased expression of toll-like receptor 7 (TLR7), which recognizes viral single-strand RNA, and potential saturation of TLR7 signaling have been observed in the peripheral $\mathrm{B}$ cells, $\mathrm{T}$ cells, and monocytes of patients with PMR (16). A recent study of transcriptional signatures in human whole blood demonstrated strong activation of TLR signaling by the of BNT162b2 vaccine, especially after the second dose (17), supporting the possible role of mRNA in vaccines as a trigger of PMR through TLR activation.

Another component of the BNT162b2 vaccine is polyethylene glycol (PEG)-conjugated lipid shells that encapsulate the mRNA (8). A similar lipid envelope was approved by the U.S. Food and Drug Administration in 1995 for use in Doxil $^{\circledR}(18)$ and has also been used in ONPATTRO ${ }^{\circledR}$ as an envelope for small interfering RNA (19). PEG has been speculated to be the major cause of anaphylaxis to BNT162 b2 (20), and acute infusion reactions have been reported as major adverse reactions to these materials (21); however, to our knowledge, there have been no such reports concerning PMR.

Generally, antibody-mediated immunity is not considered to play an essential role in the onset of PMR (22), so antibodies raised by vaccines were not considered to be a potential cause in this case. Several reports have described the development of PMR after influenza vaccination as an autoim- 


\section{(A)}

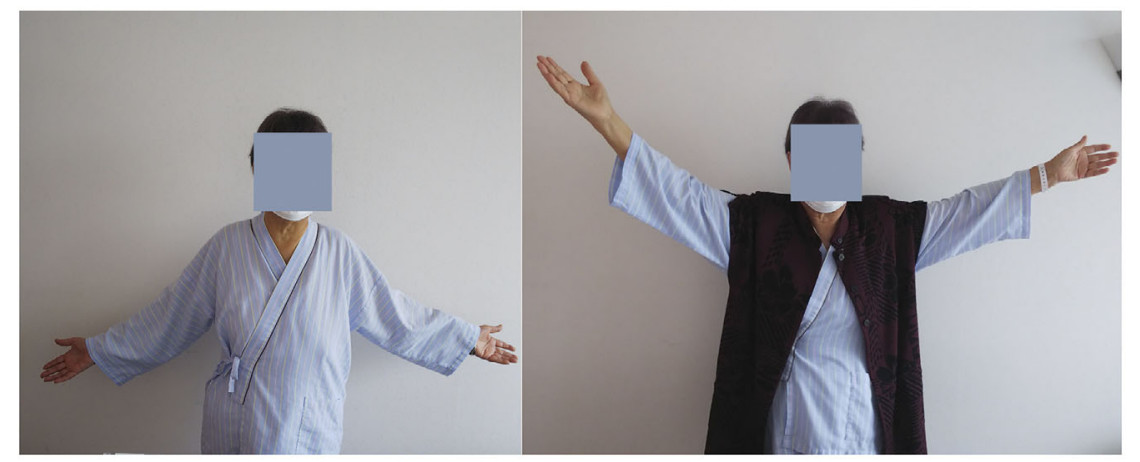

(B)

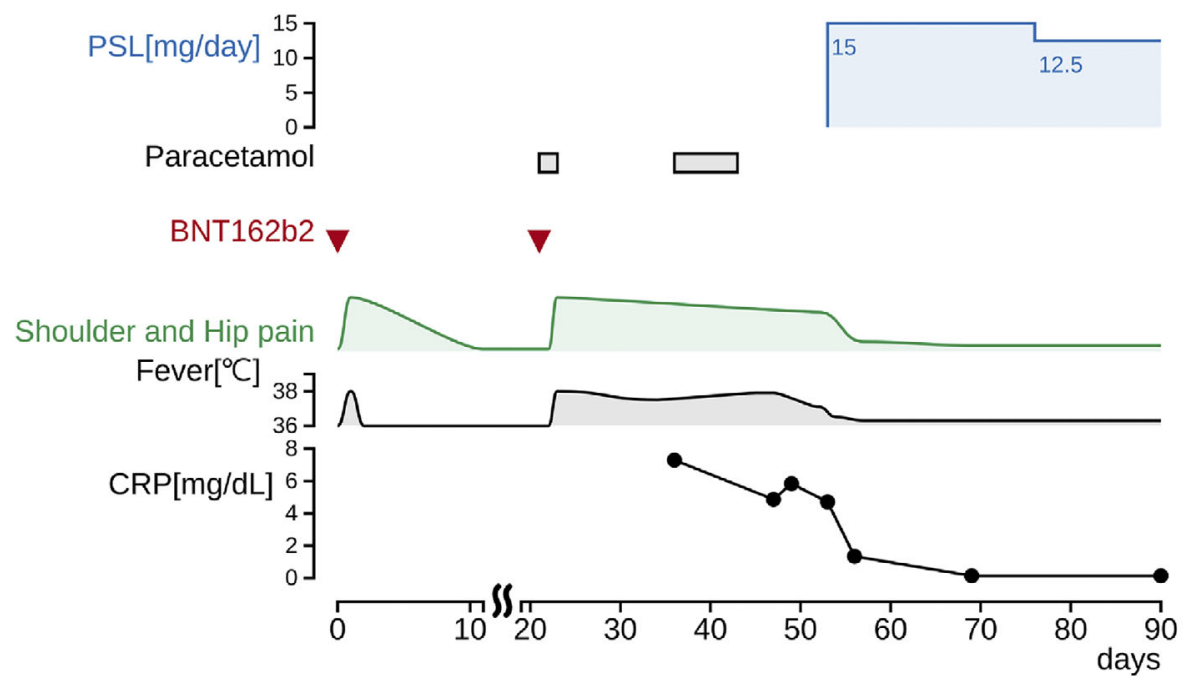

Figure 2. Clinical course. (A) Restricted range of motion in the shoulders before (left) and two days after administration (right) of prednisolone. (B) The clinical course of our case.

mune / inflammatory syndrome induced by adjuvants $(23,24)$. However, it has also been suggested that influenza vaccines without adjuvants might provoke PMR (25), so the precise mechanism remains unclear.

Although we were unable to examine the genetic profile of our patient, some reports have indicated an association between the onset of PMR and factors such as HLA-DRB1 *04 alleles $(26,27)$ and polymorphisms in the ICAM-1 gene and the promoter region of interleukin $6(28,29)$. In patients who develop PMR after influenza vaccination, DRB1*13:01 has been identified as a risk haplotype (30). In addition, some genetic backgrounds might predispose individuals to the development of PMR after the administration of mRNA vaccines.

According to our literature search, arthritis associated with COVID-19 is characterized mainly as reactive arthritis and remits in an average of 27.4 days (range, 6 to 90 days) with short-term administration of non-steroidal antiinflammatory drugs (NSAIDs) or glucocorticoids (GCs) (31-44). However, whether or not the PMR in our case was transient and self-limiting needs to be discussed.
Before the GC era, Barber et al. reported that 9 of 12 cases of PMR showed spontaneous remission with a mean duration of 14.9 months (range, 7 to 44 months) (45). In 13 patients who developed PMR after influenza vaccination, 3 showed spontaneous remission with a mean duration of 6.3 months (range, 4 to 9 months), while 9 were treated with GCs. Among these nine cases, two continued GCs for over two years, and one required methotrexate due to refractory disease (30). Tingle et al. reported seven cases of arthritis after rubella vaccination. Among these cases, arthritis persisted in 4 cases at 6 months and in 2 cases at 18 and 24 months after the onset (46). Among 11 patients who developed arthritis after hepatitis B vaccination, 3 cases resolved within an average of 7.3 months (range, 2 to 12 months) with short-term NSAIDs or GCs, while 6 cases persisted at the time of follow-up (average, 36.3 months; range, 6 to 72 months), despite treatment with a disease-modifying antirheumatic drug (47). A recent study of arthritis that developed after COVID-19 mRNA vaccination found that 2 of 9 cases remitted spontaneously with administration of only NSAIDs, while the others were treated with GCs (10). Be- 
cause the clinical course differed in each case, we cannot conclude that the PMR in our case would have spontaneously improved without treatment with prednisolone.

Although the long-term prognosis in our case is unclear due to the limited data, the administration of prednisolone $15-20 \mathrm{mg} /$ day was effective both in the present case and in previously reported cases after BNT162b2 vaccination $(11,12)$. Importantly, the benefit of vaccination against COVID-19 outweighs the risk of new-onset PMR, as PMR alone does not affect mortality (22).

It is possible that the onset of PMR in this case might have been unrelated to the vaccination. Although our case showed typical symptoms and fulfilled the classification criteria of PMR, we must also consider the possibility that this was a case of some "PMR-like syndrome" that is fundamentally different from true PMR. A further study in additional cases is needed to clarify these issues.

In conclusion, we encountered a case of PMR following the administration of an mRNA COVID-19 vaccine. PMR should be considered as a differential diagnosis in cases of long-lasting myalgia after the vaccination. However, this is likely a very rare event, and the benefits of the vaccine cannot be dismissed, as SARS-CoV-2 infection poses a much greater risk than PMR.

The authors state that they have no Conflict of Interest (COI).

\section{References}

1. Buttgereit F, Matteson EL, Dejaco C. Polymyalgia Rheumatica and Giant Cell Arteritis. JAMA 324: 993-994, 2020.

2. Meliconi R, Pulsatelli L, Uguccioni M, Salvarani C, Macchioni P, Melchiorri $\mathrm{C}$, et al. Leukocyte infiltration in synovial tissue from the shoulder of patients with polymyalgia rheumatica. Quantitative analysis and influence of corticosteroid treatment. Arthritis Rheum 39: 1199-1207, 1996.

3. Meliconi R, Pulsatelli L, Melchiorri C, Frizziero L, Salvarani C, Macchioni $\mathrm{P}$, et al. Synovial expression of cell adhesion molecules in polymyalgia rheumatica. Clin Exp Immunol 107: 494-500, 1997.

4. Zen-nyoji A, Shimizu H, Ohtani K, Oshimoto K, Kobayashi Y, Mori M. Increased RAHA titer and interleukin-6 levels in the synovial fluid in a patient with polymyalgia rheumatica. Intern Med Tokyo Jpn 32: 484-486, 1993.

5. Kreiner F, Langberg H, Galbo H. Increased muscle interstitial levels of inflammatory cytokines in polymyalgia rheumatica. Arthritis Rheum 62: 3768-3775, 2010.

6. Samson M, Audia S, Fraszczak J, Trad M, Ornetti P, Lakomy D, et al. Th1 and Th17 lymphocytes expressing CD161 are implicated in giant cell arteritis and polymyalgia rheumatica pathogenesis. Arthritis Rheum 64: 3788-3798, 2012.

7. Nakajima S, Chiba A, Makiyama A, Hayashi E, Murayama G, Yamaji $\mathrm{K}$, et al. Association of mucosal-associated invariant $\mathrm{T}$ cells with different disease phases of polymyalgia rheumatica. Rheumatol Oxf Engl 59: 2939-2946, 2020.

8. Walsh EE, Frenck RW, Falsey AR, Kitchin N, Absalon J, Gurtman A, et al. Safety and Immunogenicity of Two RNA-Based Covid-19 Vaccine Candidates. N Engl J Med 383: 2439-2450, 2020.

9. Polack FP, Thomas SJ, Kitchin N, Absalon J, Gurtman A, Lockhart S, et al. Safety and Efficacy of the BNT162b2 mRNA Covid-19 Vaccine. Safety and Efficacy of the BNT162b2 mRNA
Covid-19 Vaccine 383: 2603-2615, 2020.

10. Watad A, De Marco G, Mahajna H, Druyan A, Eltity M, Hijazi N, et al. Immune-Mediated Disease Flares or New-Onset Disease in 27 Subjects Following mRNA/DNA SARS-CoV-2 Vaccination. Vaccines 9: 435, 2021

11. Rozin P A. Are subdeltoid bursitis and polymyalgia rheumatica preferances of COVID-19 vaccine? Int J Clin Rheumatol 16: 088, 2021.

12. Manzo C, Natale M, Castagna A. Polymyalgia rheumatica as uncommon adverse event following immunization with COVID-19 vaccine: A case report and review of literature. AGING Med 1-5, 2021.

13. Dasgupta B, Cimmino MA, Kremers HM, Schmidt WA, Schirmer M, Salvarani C, et al. 2012 Provisional classification criteria for polymyalgia rheumatica: a European League Against Rheumatism/ American College of Rheumatology collaborative initiative. Arthritis Rheum 64: 943-954, 2012.

14. Cimmino MA, Grazi G, Balistreri M, Accardo S. Increased prevalence of antibodies to adenovirus and respiratory syncytial virus in polymyalgia rheumatica. Clin Exp Rheumatol 11: 309-313, 1993.

15. Uddhammar A, Boman J, Juto P, Rantapää Dahlqvist S. Antibodies against Chlamydia pneumoniae, cytomegalovirus, enteroviruses and respiratory syncytial virus in patients with polymyalgia rheumatica. Clin Exp Rheumatol 15: 299-302, 1997.

16. Rodríguez LÁ, López-Hoyos M, Mata C, Fontalba A, Alen JC, Marín MJ, et al. Expression and function of toll-like receptors in peripheral blood mononuclear cells of patients with polymyalgia rheumatica and giant cell arteritis. Ann Rheum Dis 70: 1677-1683, 2011.

17. Arunachalam PS, Scott MKD, Hagan T, Li C, Feng Y, Wimmers $\mathrm{F}$, et al. Systems vaccinology of the BNT162b2 mRNA vaccine in humans. Nature 596: 410-416, 2021.

18. Goebel FD, Goldstein D, Goos M, Jablonowski H, Stewart JS. Efficacy and safety of Stealth liposomal doxorubicin in AIDS-related Kaposi's sarcoma. The International SL-DOX Study Group. Br J Cancer 73: 989-994, 1996.

19. Akinc A, Maier MA, Manoharan M, Fitzgerald K, Jayaraman M, Barros S, et al. The Onpattro story and the clinical translation of nanomedicines containing nucleic acid-based drugs. Nat Nanotechnol 14: 1084-1087, 2019.

20. Castells MC, Phillips EJ. Maintaining Safety with SARS-CoV-2 Vaccines. N Engl J Med 384: 643-649, 2021.

21. Moghimi SM. Nanomedicine safety in preclinical and clinical development: focus on idiosyncratic injection/infusion reactions. Drug Discov Today 23: 1034-1042, 2018.

22. González-Gay MA, Matteson EL, Castañeda S. Polymyalgia rheumatica. Lancet Lond Engl 390: 1700-1712, 2017.

23. Perez C, Maravi E. Polymyalgia rheumatica following influenza vaccination. Muscle Nerve 23: 824-825, 2000.

24. Liozon E, Ittig R, Vogt N, Michel JP, Gold G. Polymyalgia rheumatica following influenza vaccination. J Am Geriatr Soc 48: 1533-1534, 2000.

25. McElhaney JE, Beran J, Devaster J-M, Esen M, Launay O, Leroux-Roels G, et al. AS03-adjuvanted versus non-adjuvanted inactivated trivalent influenza vaccine against seasonal influenza in elderly people: a phase 3 randomised trial. Lancet Infect Dis 13: 485-496, 2013.

26. Weyand CM, Hunder NN, Hicok KC, Hunder GG, Goronzy JJ. HLA-DRB1 alleles in polymyalgia rheumatica, giant cell arteritis, and rheumatoid arthritis. Arthritis Rheum 37: 514-520, 1994.

27. Combe B, Sany J, Le Quellec A, Clot J, Eliaou JF. Distribution of HLA-DRB1 alleles of patients with polymyalgia rheumatica and giant cell arteritis in a Mediterranean population. J Rheumatol 25: 94-98, 1998.

28. Amoli MM, Shelley E, Mattey DL, Garcia-Porrua C, Thomson W, Hajeer $\mathrm{AH}$, et al. Intercellular adhesion molecule-1 gene polymor- 
phisms in isolated polymyalgia rheumatica. J Rheumatol 29: 502504, 2002.

29. Boiardi L, Casali B, Farnetti E, Pipitone N, Nicoli D, Cantini F, et al. Relationship between interleukin 6 promoter polymorphism at position -174, IL-6 serum levels, and the risk of relapse/recurrence in polymyalgia rheumatica. J Rheumatol 33: 703-708, 2006.

30. Liozon E, Parreau S, Filloux M, Dumonteil S, Gondran G, Bezanahary H, et al. Giant cell arteritis or polymyalgia rheumatica after influenza vaccination: A study of 12 patients and a literature review. Autoimmun Rev 20: 102732, 2021.

31. Kocyigit BF, Akyol A. Reactive arthritis after COVID-19: a casebased review. Rheumatol Int 41: 2031-2039, 2021.

32. Hønge BL, Hermansen M-LF, Storgaard M. Reactive arthritis after COVID-19. BMJ Case Rep 14: e241375, 2021.

33. El Hasbani G, Jawad A, Uthman I. Axial and peripheral spondyloarthritis triggered by sars-cov-2 infection: a report of two cases. Reumatismo 73: 59-63, 2021.

34. Coath FL, Mackay J, Gaffney JK. Axial presentation of reactive arthritis secondary to COVID-19 infection. Rheumatol Oxf Engl 60: e232-e233, 2021.

35. Saricaoglu EM, Hasanoglu I, Guner R. The first reactive arthritis case associated with COVID-19. J Med Virol 93: 192-193, 2021.

36. Jali I. Reactive Arthritis After COVID-19 Infection. Cureus 12: e 11761, 2020.

37. De Stefano L, Rossi S, Montecucco C, Bugatti S. Transient monoarthritis and psoriatic skin lesions following COVID-19. Ann Rheum Dis annrheumdis-2020-218520, 2020.

38. Gasparotto M, Framba V, Piovella C, Doria A, Iaccarino L. PostCOVID-19 arthritis: a case report and literature review. Clin Rheumatol 40: 3357-3362, 2021.

39. Sureja NP, Nandamuri D. Reactive arthritis after SARS-CoV-2 in- fection. Rheumatol Adv Pract 5: rkab001, 2021.

40. Danssaert Z, Raum G, Hemtasilpa S. Reactive Arthritis in a 37Year-Old Female With SARS-CoV2 Infection. Cureus 12: e9698, 2020.

41. Shokraee K, Moradi S, Eftekhari T, Shajari R, Masoumi M. Reactive arthritis in the right hip following COVID-19 infection: a case report. Trop Dis Travel Med Vaccines 7: 18, 2021.

42. Gibson M, Sampat K, Coakley G. EP15 A self-limiting symmetrical polyarthritis following COVID-19 infection. Rheumatol Adv Pract 4: 2020Epub ahead of print octubre de.

43. Mukarram MS. Post COVID-19 Reactive Arthritis: An Emerging Existence In The Spectrum Of Musculoskeletal Complications Of SARS-CoV-2 Infection. Clin Stud Med Case Rep 7: 1-4, 2020.

44. Cincinelli G, Di Taranto R, Orsini F, Rindone A, Murgo A, Caporali R. A case report of monoarthritis in a COVID-19 patient and literature review: Simple actions for complex times. Medicine (Baltimore) 100: e26089, 2021.

45. Barber HS. Myalgic Syndrome with Constitutional Effects: Polymyalgia Rheumatica. Ann Rheum Dis 16: 230-237, 1957.

46. Tingle AJ, Allen M, Petty RE, Kettyls GD, Chantler JK. Rubellaassociated arthritis. I. Comparative study of joint manifestations associated with natural rubella infection and RA 27/3 rubella immunisation. Ann Rheum Dis 45: 110-114, 1986.

47. Maillefert JF, Sibilia J, Toussirot E, Vignon E, Eschard JP, Lorcerie B, et al. Rheumatic disorders developed after hepatitis B vaccination. Rheumatology 38: 978-983, 1999.

The Internal Medicine is an Open Access journal distributed under the Creative Commons Attribution-NonCommercial-NoDerivatives 4.0 International License. To view the details of this license, please visit (https://creativecommons.org/licenses/ by-nc-nd/4.0/).

(C) The Japanese Society of Internal Medicine Intern Med Advance Publication 